\title{
AROMA PROFILE OF EUCALYPTUS GLOBULUS: COLLECTED FROM NORTH WEST KARNATAKA, INDIA
}

\author{
R. K. Joshi* \\ *Department of Phytochemistry, Regional Medical Research Centre (ICMR), \\ Belgaum, Karnataka-590 010, India.
}

\begin{abstract}
The chemical composition of the essential oil of the leaves of Eucalyptus globulus (Myrtaceae) grown in North West Karnataka, has been analyzed by GC and GC/MS. Forty-eight constituents were identified, accounting 97.93\% of the total oil. The major compounds were á-phellandrene (40.31\%), á-pinene (13.71\%), â-pinene (13.31\%), ã-terpinene (9.61\%) and 1,8-cineol (4.96\%). The oil was rich in monoterpene hydrocarbons (81.14\%).
\end{abstract}

Keywords: Eucalyptus globulus; Myrtaceae; Essential oil; á -phellandrene; GC/MS.

\section{INTRODUCTION}

The Myrtaceae family comprises approximately 130 genera and 3000 species of trees and shrubs ${ }^{1}$. Eucalyptus globulus is an ever green tree growing up to 40 to $70 \mathrm{~m}$ and widely planted in the sub tropical and Mediterranean regions ${ }^{2}$. The fresh leaves are sometimes eating as vegetables, while the dry leaves were often smoked as cigarettes for treatment of asthma ${ }^{3}$. It is also to be useful in the various treatments of lung ailment, malaria, bladder and liver infection ${ }^{4}$. Diverse pharmacological activities like antihyperglycemic ${ }^{5}$, hypoglycemic $^{6}$, antioxidant ${ }^{7}$, antibacterial ${ }^{8}$ and antifungal ${ }^{9}$ have been reported. Essential oil derived from Eucalyptus globulus exhibited antimicrobial ${ }^{10,11}$, analgesic, antiinflammatory $^{12}$ and insecticidal ${ }^{13,14}$ activities. Various compounds such as 1,8-cineole, á-pinene and d-limonene ${ }^{13}$ from India, á-pinene, á-terpineol, globulol and aromadendrene from Argentina ${ }^{14}$, á-pinene and 1,8-cineole ${ }^{16}$ from Ethiopia, aromadendrene, á-phellandrene, 1,8-cineole, ledene and globulol $^{17}$ from Portugal, 1,8-cineol and á-pinene ${ }^{18}$ from Tunisia, terpinen-4-ol, ã-terpinene, spathulenol, ñ-cymene, ñ-cymen-7-ol, globulol and á-phellandrene ${ }^{19}$ from Nigeria, 1,8-cineole, limonene, á-pinene and o-Cymene ${ }^{14}$ from Brazil have been reported. In this communication presents the chemical composition of the essential oil of Eucalyptus globulus collected from Western Ghats region of North West Karnataka, India and to demarcate the terpenoid profile.

\section{EXPERIMENTAL}

\section{Plant material}

The leaves of Eucalyptus globulus were collected from district Belgaum (N 15.88668; E 74.52353), Karnataka, India, in the month of October, 2011. The plant was identified by Dr. H. V. Hegde, Scientist, Regional Medical Research Centre (ICMR), Belgaum, Karnataka, India, where voucher specimen (No. RMRC-586) has been deposited.

\section{Isolation of essential oil}

The fresh plant materials (200 g) were hydro-distilled for $3 \mathrm{~h}$ using a Clevenger type apparatus. The oil was dried over anhydrous sodium sulfate and stored at $-4{ }^{\circ} \mathrm{C}$ until analysis. The yield of oils was $0.3 \%$.

Analysis of oil

The gas chromatography (GC) analysis of the oil was carried out on Varian 450 gas chromatograph equipped with FID, using stationary phase CP Sil-8-CB (30 m x 0.25 mm i.d., 0.25 ìm film thickness) fused silica capillary column. Nitrogen was a carrier gas at $1.0 \mathrm{~mL} / \mathrm{min}$ flow rate. Temperature programming was $60{ }^{\circ} \mathrm{C}-220{ }^{\circ} \mathrm{C}$ at $3{ }^{\circ} \mathrm{C} / \mathrm{min}$, for injector and detector temperatures were $230{ }^{\circ} \mathrm{C}$ and $250{ }^{\circ} \mathrm{C}$, respectively. The injection volume was 1.0 ì diluted in $n$-hexane, split ratio was 1: 50 . The gas chromatography-mass spectrometry (GCMS) analysis of the oil was carried out on Thermo Scientific Trace Ultra GC interfaced with a Thermo Scientific ITQ 1100 Mass Spectrometer fitted with TG-5 fused silica capillary column (30 m x $0.25 \mathrm{~mm}$ i.d., 0.25 ìm film thickness). The column temperature was programmed from $60^{\circ} \mathrm{C}-220^{\circ} \mathrm{C}$ at $3^{\circ} \mathrm{C} / \mathrm{min}$, using He as a carrier gas at $1.0 \mathrm{~mL} / \mathrm{min}$. The injector temperature was $230^{\circ} \mathrm{C}$, injection size $0.1 \mathrm{i} \mathrm{L}$ prepared in $n$-hexane, split ratio 1:50. MS were taken at $70 \mathrm{eV}$ with mass scan range of 40 - $450 \mathrm{amu}$.

\section{Identification of the components}

Identification of constituents were done on the basis of Retention Index (RI, determined with reference to homologous series of $n$-alkanes $\mathrm{C}_{8}-\mathrm{C}_{28}$, under identical experimental condition), MS library search (NIST and WILEY), and by comparison with MS literature data ${ }^{20}$. The relative amounts of individual components were calculated based on GC peak area (FID response) without using correction factor.

\section{RESULTS AND DISCUSSION}

The chemical composition of essential oil of the leaves of Eucalyptus globulus is presented in Table 1. The constituents of leaves oil of Eucalyptus globulus are listed in order of their elution order on the TG-5 column. In total of forty-eight compounds were identified from the oil representing $97.93 \%$

Author for Correspondence: R. K. Joshi, Department of Phytochemistry, Regional Medical Research Centre (ICMR), Belgaum, Karnataka-590 010, India. Email: joshirk_natprod@yahoo.com. 
Table 1: Chemical composition of the essential oil of Eucalyptus globulus.

\begin{tabular}{|c|c|c|c|}
\hline Compound & $\%$ & RI Lit & Identification \\
\hline á-Thujene & 1.15 & 938 & RI,MS \\
\hline á-Pinene & 13.71 & 943 & RI,MS \\
\hline á-Fenchene & 0.03 & 956 & RI,MS \\
\hline Camphene & 0.09 & 958 & RI,MS \\
\hline â-Pinene & 13.31 & 986 & RI,MS \\
\hline Myrcene & 0.01 & 995 & RI,MS \\
\hline á-Phellandrene & 40.31 & 1011 & RI,MS \\
\hline á-Terpinene & 0.05 & 1023 & RI,MS \\
\hline p-Cymene & 1.20 & 1032 & RI,MS \\
\hline Limonene & 0.49 & 1038 & RI,MS \\
\hline 1,8-Cineol & 4.96 & 1040 & RI,MS \\
\hline (E)-â-Ocimene & 0.02 & 1057 & RI,MS \\
\hline$\tilde{a}$-Terpinene & 9.61 & 1068 & RI,MS \\
\hline cis-Linalool oxide & 0.11 & 1081 & RI,MS \\
\hline$p$-Mentha-2,4(8)-diene & 1.16 & 1092 & RI,MS \\
\hline endo-Fenchol & 0.14 & 1117 & RI,MS \\
\hline cis-p-Menth-2-en-1-ol & 0.27 & 1126 & RI,MS \\
\hline trans-Pinene hydrate & 0.18 & 1147 & RI,MS \\
\hline Borneol & 0.21 & 1171 & RI,MS \\
\hline Terpin-4-ol & 2.29 & 1185 & RI,MS \\
\hline á-Terpineol & 2.25 & 1196 & RI,MS \\
\hline cis-Piperitol & 0.05 & 1198 & RI,MS \\
\hline trans-Piperitol & 0.09 & 1211 & RI,MS \\
\hline Carvotanacetone & 0.18 & 1251 & RI,MS \\
\hline Thymol & $\mathrm{t}$ & 1298 & RI,MS \\
\hline Carvacrol & $\mathrm{t}$ & 1304 & RI,MS \\
\hline Eugenol & $\mathrm{t}$ & 1362 & RI,MS \\
\hline Cyclosativene & 0.03 & 1375 & RI,MS \\
\hline á-Ylangene & $\mathrm{t}$ & 1378 & RI,MS \\
\hline Methyl eugenol & 0.03 & 1407 & RI,MS \\
\hline á-Gurjunene & 0.04 & 1413 & RI,MS \\
\hline â-Caryophyllene & 0.21 & 1425 & RI,MS \\
\hline$\hat{a}$-Gurjunene & 0.11 & 1437 & RI,MS \\
\hline Aromadendrene & 0.04 & 1445 & RI,MS \\
\hline á-Humulene & 0.02 & 1459 & RI,MS \\
\hline Seychellene & $\mathrm{t}$ & 1467 & RI,MS \\
\hline â-Selinene & 0.05 & 1493 & RI,MS \\
\hline á-Selinene & $\mathrm{t}$ & 1501 & RI,MS \\
\hline$\tilde{a}$-Cadinene & 0.02 & 1520 & RI,MS \\
\hline$\ddot{a}$-Cadinene & $\mathrm{t}$ & 1532 & RI,MS \\
\hline Elemol & $\mathrm{t}$ & 1556 & RI,MS \\
\hline Caryophyllene oxide & 0.02 & 1589 & RI,MS \\
\hline Khusimone & $\mathrm{t}$ & 1599 & RI,MS \\
\hline Guaiol & $\mathrm{t}$ & 1601 & RI,MS \\
\hline 10-epi-ã-Eudesmol & 1.72 & 1627 & RI,MS \\
\hline$\tilde{a}$-Eudesmol & 0.14 & 1639 & RI,MS \\
\hline Cubenol & 2.04 & 1651 & RI,MS \\
\hline á-Muurolol & 1.59 & 1655 & RI,MS \\
\hline Monoterpene hydrocarbons & 81.14 & & \\
\hline Oxygenated monoterpenes & 10.73 & & \\
\hline Sesquiterpene hydrocarbons & 0.55 & & \\
\hline Oxygenated sesquiterpenes & 5.51 & & \\
\hline Phenyl derivatives & $\mathrm{t}$ & & \\
\hline Total & $97.93 \%$ & & \\
\hline
\end{tabular}

't' $=\operatorname{trace}(<0.01 \%)$

of the total oil. The major compounds were á-phellandrene (40.31\%), á-pinene (13.71\%), â-pinene (13.31\%), ã-terpinene (9.61\%) and 1,8-cineol (4.96\%). The oil was rich in monoterpene hydrocarbons (81.14\%) followed by oxygenated monoterpenes (10.73\%), oxygenated sesquiterpenes (5.51\%), sesquiterpene hydrocarbons (0.55\%) and phenyl derivatives $(<0.01 \%)$. The quantitative and qualitative divergence from other regions may be due to the geographical, climatic and soil conditions in the southern part of India, which in turn may affect the composition and other secondary metabolites of the plant. The present finding is intended as a contribution to the better knowledge of the chemical composition of the essential oil of the leaves of Eucalyptus globulus.

\section{ACKNOWLEDGEMENTS}

The author is grateful to the Dr. S. D. Kholkute, Director-inCharge, Regional Medical Research Centre (ICMR) Belgaum, Karnataka, India for providing necessary facilities and also thankful to Mr. Manjunath Patil, Laboratory Attendant, Department of Phytochemistry, RMRC, Belgaum for collection of plant materials and extraction of essential oil.

\section{REFERENCES}

1. Watson, L. and Dallwitz, M.J. 2007. The families of flowering plants: descriptions, illustrations, identification, and information retrieval. Available at: http://delta-intkey.com.

2. Little, E.L.J. 1983. Common fuel wood crops: A handheld book for their identification.

3. Brooker, S.G., Cammbie, R.C. and Cooper, R.C. 1999. New Zealand medicinal plants. Heinemann.

4. Boukef, K., Balanshad, G., Lallemand, M. and Brenard, P. 1976. Study of flavonic heterosides and aglycones isolated from the leaves of Eucalyptus globulus.

5. Gøray, A.M. and Flatt, P.R. 1998. Journal of Nutrition. 128: 2319-2323.

6. Jouad, H., Maghrani, M., El Hassani, R.A. and Eddouks, M. 2003. Journal of Herbs, Spices and Medicinal Plants. 10: 1928.

7. Nakhaee, A., Bokaeian, M., Saravani, M., Farhangi, A. and Akbarzadeh, A. 2009. Indian Journal of Clinical Biochemistry. 24: 419-425.

8. Salari, M.H., Amine, G., Shirazi, M.H., Hafezi, R. and Mohammadypour, M. 2006. Clinical Microbiology and Infection. 12: 194-196.

9. Canhoto, C. and Graca, M.A. 1999. Microbial Ecology. 37: 163-172.

10. Gilles, M., Zhao, J., An, M. and Agboola, S. 2010. Food Chemistry. 119: 731-737.

11. Sartorelli, P., Marquioreto, A.D., Amaral-Baroli, A., Lima, M.E. and Moreno, P.R. 2007. Phytotherapy Research. 21: 231-233.

12. Silva, J. , Abebeb, W., Sousa, S.M., Duartea, V.G., Machadoc, M.I.L. and Matos, F.J.A. 2003. Journal of Ethnopharmacology. 89: 277-283.

13. Kumar, P., Mishra, S., Malik, A. and Satya, S. 2012. Acta Tropica. 122:212-218.

14. Maciel, M.V., M.V., Morais, S.M., Bevilaqua, C.M.L., Silva, R.A., Barros, R.S., Sousa, R.N., Sousa, L.C., Brito, E.S. and Souza-Neto, M.A. 2010. Veterinary Parasitology. 167: 1-7.

15. Viturro, C.I., Molina, A.C. and Heit, C.I. 2003. Journal of Essential Oil Research. 15: 206-208.

16. Dagne, E., Bisrat, D., Alemayehu, M. and Worku, T. 2000. Journal of Essential Oil Research. 12: 467-470.

17. Pereira, S.I., Freire, C.S.R., Neto, C.P., Silvestre, A.J.D., Silva, A.M.S. 2005. Flavour and Fragrance Journal. 20: 407-409.

18. Noumi, E., Snoussi, M., Hajlaoui, H., Trabelsi, N., Ksouri, R., Valentin, E. and Bakhrouf, A. 2011. Journal of Medicinal Plants Research. 5: 4147-4156.

19. Akolade, J.O., Olajide, O.O., Afolayan, M.O., Akande, S.A., Idou, D.I. and Orishadipe, A.T. 2012. Journal of Natural Product and Plant Resourse. 2: 1-8.

20. Adams, R.P., 2007. Identification of Essential Oil Components by Gas Chromatography/Mass Spectrometry, Allured Publ. Corp., Carol Stream. IL. 